\title{
BUKU MUHAMMAD HIS LIFE BASED ON THE EARLIEST SOURCES KARYA MARTIN LINGS: SEBUAH KAJIAN HISTORIOGRAFI
}

\author{
Muhammad Irham, Agus Permana \\ Fakultas Adab dan Humaniora, Universitas Islam Negeri \\ Sunan Gunung Djati Bandung \\ Email: irhammuh24@gmail.com
}

\begin{abstract}
The book of "Muhammad: His Life Based on Earliest Sources" was written by Martin Lings, who after converting to Islam got the name Abu Bakar Sirajuddin. Since it was first published in 1983, this book has received many awards and has been translated into 10 languages. This book discusses the biography of the Prophet Muhammad and uses classical sources that are so authoritative from the 2 nd century $D / 8 M$ and $3 \mathrm{D} / 9 \mathrm{M}$. This research aims to find out the life history and work of Martin Lings, the contents of the book Muhammad His Life based on the Earliest Sources, and their historiographic analysis. The method used is a historical research method which consists of four stages, namely heuristics (collection of sources), criticism (selection of sources), interpretation (interpretation of data), and historiography (writing of history). Based on research that has been done, it is known that Martin Lings came from England and in 1938 he converted to Islam. He died in 2005 in England. Muhammad's book: His Life Based on Earliest Sources, written by Martin Lings, first published in 1983. This book is divided into 85 parts which can be collected into 4 groups, namely before the birth of the Prophet Muhammad, the life of the Prophet Muhammad in Mecca, the life of the Prophet Muhammad in Medina and Islamic themes. In it, Lings selects the source he uses so he only chooses the earliest source. The style of writing Muhammad His Life's book based on the Earliest Sources by Martin Lings is a type of Sirah included in the biographical tradition in Muslim historiography. The uniqueness that is contained in this book is; the author is a convert to Islam and Sufi, uses authentic sources, written in literary language, and combines socio-cultural analysis with the reading of scriptures and hadith, and also includes stories of miracles.
\end{abstract}

Keywords: Historiography, Martin Lings, Sirah. 


\section{Pendahuluan}

Penulisan sejarah atau historiografi di dunia muslim berawal dari keinginan untuk mengenang Nabi Muhammad Saw. Beliau merupakan manusia paling sempurna di benak kaum muslim. Ucapan dan perilakunya sesuai dengan isi kitab suci al-Qur'an. Ditambah lagi dengan penegasan alQur'an; "Ucapannya itu tiada lain hanyalah wahyu yang diwahyukan (kepadanya)" dan juga "Sesungguhnya telah ada pada (diri) Rasulullah itu suri teladan yang baik bagimu (yaitu) bagi orang yang mengharap (rahmat) Allah dan (kedatangan) hari kiamat dan dia banyak menyebut Allah."

Pada periode klasik karya-karya sejarah Islam diwarnai dengan kajian seputar perang-perang Nabi yang dikenal dengan Maghazi. Karya ini membahas kisah tentang peperangan dan penaklukan-penaklukan yang dilakukan oleh Rasulullah Saw. Pada awalnya, penulisan Maghazi dilakukan semata-mata hanya untuk kepentingan dan legitimasi para khalifah dalam menerapkan berbagai kebijakan futuhiyyah (penaklukan wilayah). ${ }^{3}$ Namun selanjutnya berkembang menjadi penulisan sejarah hidup Nabi Muhammad Saw yang bukan hanya membahas peperangan-peperangannya saja, tetapi juga riwayat hidup beliau secara lebih komprehensif: dari kelahiran hingga wafatnya, atau yang akrab disebut dengan sirah.

Secara semantik sirah berarti perjalanan. Dalam terminologi historiografi, sirah berarti perjalanan hidup atau biografi seorang tokoh. Apabila disebut Sirah Nabawiyah atau Sirah saja, maka yang dimaksud adalah perjalanan hidup atau biografi Nabi Muhammad Saw. Demikian pentingnya pengetahuan tentang sejarah perjalanan hidup Nabi, sehingga sirah dipandang sebagai ilmu yang sangat penting dalam keilmuan Islam, ${ }^{4}$ dan menjadi titik awal perkembangan penulisan biografi dalam historiografi Islam.

Para sejarawan yang menjadi pionir dalam penulisan Sirah Nabawiyah adalah Urwah bin Zubair (w. 94 H/712 M), ${ }^{5}$ Aban bin Utsman (w.

\footnotetext{
${ }^{1}$ Q.S. an-Najm: 4.

${ }^{2}$ Q.S. al-Ahzab: 21.

3 Ajid Thohir, Sirah Nabawiyah: Nabi Muhammad Saw dalam Kajian Ilmu SosialHumaniora, Bandung: Penerbit Marja, 2014, hlm. 40-41.

${ }^{4}$ Badri Yatim, Historiografi Islam, hlm. 196-197.

${ }^{5}$ Urwah bin Zubair bin Awwam termasuk generasi tabi'in. Kemungkinan Urwah wafat pada tahun 94 H/713 M. Tarif Khalidi, Arabic Historical Thought in the Classical Period, hlm. 30. Gregor Schoeler, The Biography of Muhammad: Nature and Authenticity, New York: Routledge, 2011, hlm. 21.
} 
$105 \mathrm{H}),{ }^{6}$ Syurahbil bin Sa'ad (w. $\left.123 \mathrm{H}\right)$, Wahab bin Munabbih (w. $\left.110 \mathrm{H}\right),{ }^{7}$ dan Ibnu Syihab az-Zuhri (w. 124 H/ 742 M). ${ }^{8}$ Naskah tulisan mereka semua sudah punah ditelan zaman, yang tersisa hanya kutipan-kutipan yang dapat kita temukan dalam tulisan Sirah generasi-generasi selanjutnya. Generasi tertua yang dapat ditemui teksnya dimulai dari Muhammad bin Ishak (w. 152 H), kemudian al-Waqidi (w. 203 H), Muhammad bin Sa'ad (w. 130 H), dan Ibn Hisyam (w. 218 H) yang menulis Sirahnya sendiri dengan banyak memanfaatkan Sirah karya Muhammad bin Ishaq. ${ }^{9}$

Di masa modern seperti sekarang, biografi Nabi Muhammad ditulis bukan hanya oleh orang Arab, tetapi juga orang Eropa. Orang Islam juga tidak hanya terbatas di Asia dan Afrika seperti dulu, tetapi menyebar hingga pusatpusat peradaban Barat, seperti Amerika dan Jerman. Malah pengaruh sejarawan Eropa juga terasa di dunia muslim, entah di pihak yang mendukung Orientalisme ${ }^{10}$ maupun tidak. Dari abad ke-19, salah satu contoh karya orang Barat yang ikut menyoroti pribadi Nabi Muhammad ialah On Heroes, HeroWorship and the Heroic in History, karya Thomas Carlyle dan The Life of Mahomet karya Sir William Muir. Sedangkan dari abad ke-20 hingga sekarang, sudah sangat banyak sarjana Barat yang menghasilkan studi tentang Nabi, seperti Maxime Rodinson, ${ }^{11}$ Tilman Nagel, ${ }^{12}$ Karen Armstrong, ${ }^{13}$ dan

\footnotetext{
${ }^{6}$ Aban bin Utsman bin Affan adalah putra dari khalifah ketiga, Utsman bin Affan. Beliau wafat di masa Khalifah Yazid bin Abdul Malik. K. V. Zettersteen, "Aban b. Uthman" dalam H. A. R. Gibbs dkk., Encyclopaedia of Islam New Edition, jilid 1, Leiden: Brill, 1986, hlm. 23 .

${ }^{7}$ Abu Abdullah Wahab bin Munabbih berasal dari Yaman. Riwayat-riwayat dari dirinya, terutama kisah nabi-nabi dari Bani Israil, banyak dikutip sejarawan muslim dan para ahli hadits. Lihat R.G. Khoury, "Wahb b. Munabbih", dalam Peri Bearman dkk., Encyclopaedia of Islam New Edition, jilid 11, Leiden: Brill, 1997.

${ }^{8}$ Syihab az-Zuhri adalah murid dari Urwah bin Zubair dan Aban bin Utsman. Beliau wafat pada tahun 124 H/742 M. Gregor Schoeler, The Biography of Muhammad ..., hlm. 23-25.

${ }^{9}$ Ajid Thohir, Sirah Nabawiyah..., hlm. 32.

${ }^{10}$ Orientalisme didefinisikan Edward Said sebagai: "sebuah corak pemikiran yang didasari atas distingsi ontologis dan epistemologis antara Timur (yakni Asia dan Afrika) dan Barat." Lihat Edward Said, Orientalism, New York: Vintage Books, 1979, hlm. 2. Tentang pengaruh Orientalisme di dunia muslim, lihat Zaid Ahmad, "Muslim Philosophy of History" dalam Aviezer Tucker dkk., A Companion to the Philosophy of History and Historiography, Sussex: Blackwell Publishing, 2009, hlm. 443-444.

${ }^{11}$ Maxime Rodinson lahir di Paris tahun 1915. Tulisan Rodinson di antaranya ialah: The Arabs (1981), Mohammed (2002) dan Islam and Capitalism (1973). Ia meninggal dunia pada 2004. Jean-Pierre Digard, "Maxime (1915-2004)", www.lhomme.revues.org/index1546.html diakses pada 12 Juni 2019.

${ }^{12}$ Tilman Nagel lahir tahun 1942 di Cottbus, Jerman. Dia terkenal sebagai seorang orientalis yang ahli di bidang sejarah Islam. Di antara tulisannya ialah Angst vor Allah? (2014) dan Mohammed: Leben und Legende (2008).

${ }^{13}$ Karen Armstrong lahir di Inggris tahun 1944. Dia telah menulis banyak buku, seperti Holy War: The Crusades and their Impact on Today's World (1988), A History of God (1993), dan
} 
Chase F. Robinson. ${ }^{14}$ Nama-nama tersebut berasal dari latar yang beragam, tetapi punya satu kesamaan: semuanya bukan penganut Islam tetapi mempelajari kehidupan nabinya.

\section{Studi Pustaka}

Studi Pustaka merupakan "telaah terhadap pustaka atau literatur yang menjadi landasan pemikiran dalam penelitian". ${ }^{15}$ Penulis telah melakukan observasi ke pelbagai tempat guna mencari sumber-sumber yang terkait dengan judul penelitian yang penulis angkat. Hasil dari observasi tersebut, penulis menemukan beberapa literatur yang menginformasikan atau berkaitan dengan historiografi biografi Nabi. Adapun beberapa karya atau tulisan ilmiah tersebut di antaranya sebagai berikut:

Pertama, skripsi Anissia Lailatul Fitri, mahasiswa UIN Maulana Malik Ibrahim, yang berjudul Sistem Pendidikan Islam Nabi Muhammad SAW pada Buku Muhammad Super Leader Super Manager Karya Syafi'i Antonio. ${ }^{16}$ Skripsi tersebut memaparkan isi dari salah satu buku Syafi'i Antonio, seorang miliarder yang terkenal karena sukses dalam berbisnis dan berdakwah, yakni Muhammad Super Leader Super Manager. Buku itu menguraikan hidup Nabi Muhammad sebagai seorang pemimpin yang sukses dalam berdakwah dan berbisnis. Berdasarkan fokus kajiannya, dapat disimpulkan bahwa skripsi yang ditulis Lailatul Fitri berfokus pada bidang pendidikan, khususnya pendidikan bisnis.

Kedua, skripsi Tarbiyah yang berjudul Corak dan Metodologi Penulisan Sejarah Sirah Nabawiyyah Karya Ibnu Ishaq. ${ }^{17}$ Skripsi Tarbiyah untuk mendapat gelar S.Hum dari UIN Sunan Gunung Djati tersebut memaparkan isi, corak, metode, dan pengaruh dari Sirah Nabawiyah karya Ibnu Ishak, yang hidup di abad ke-2 H. Berdasarkan fokus kajiannya, dapat disimpulkan bahwa skripsi yang ditulis Tarbiyah berfokus pada kajian historiografi.

\footnotetext{
Muhammad: A Prophet of Our Time (2006). Lihat autobiografinya, yakni Karen Armstrong, The Spiral Staircase: My Climb out of Darkness, London: Anchor Books, 2004.

${ }^{14}$ Chase F. Robinson pernah menjadi professor di University of Oxford dan City University of New York. Dia adalah penulis dari Islamic Historiography (2003) dan Empire and Elites after the Muslim Conquest: The Transformation of Northern Mesopotamia (2000). Lihat Chase F. Robinson dkk, The New Cambridge History of Islam, jilid 1, New York: Cambridge University Press, 2010, hlm. xviii.

${ }^{15}$ Tim Prodi Ilmu Sejarah, Pedoman Penulisan Tugas Akhir Ilmu Sejarah, Yogyakarta: Ilmu Sejarah Fakultas Ilmu Sosial Universitas Negeri Yogyakarta, 2013, hlm. 6.

16 Anissia Lailatul Fitri, Sistem Pendidikan Islam Nabi Muhammad SAW pada Buku Muhammad Super Leader Super Manager Karya Syafi'i Antonio, skripsi UIN Maulana Malik Ibrahim, 2016.

${ }^{17}$ Tarbiyah, Corak dan Metodologi Penulisan Sejarah Sirah Nabawiyyah Karya Ibnu Ishaq, skripsi UIN Sunan Gunung Djati, 2013.
} 
Sedangkan penelitian yang mengkaji pribadi ataupun tulisan-tulisan Martin Lings secara umum belum penulis temukan. Karena itu penulis akan meneliti buku Muhammad: His Life Based on Earliest Sources karya Martin Lings. Secara etimologis, kata sejarah berasal dari bahasa Arab, yaitu syajarah, yang artinya pohon, akar, keturunan, dan asal-usul. Dinamakan demikian karena fokus awal dari pembahasan sejarah adalah penulusuran terhadap geneologi yang umumnya digambarkan seperti pohon. ${ }^{18}$ Metode atau langkah-langkah yang digunakan dalam penelitian ini yaitu menggunakan metode sejarah. Heuristik, kritik, interpretasi, dan historiografi.

\section{Pembahasan}

Martin Lings lahir di tengah keluarga Kristen Protestan di Lancashire, Inggris tahun 1909. ${ }^{19}$ Meskipun dilahirkan di Inggris, masa kecil Lings lebih banyak dihabiskan di Amerika Serikat bersama ayahnya. Beranjak remaja, Lings kembali ke Inggris dan mendapat pendidikan Protestan di Bristol. ${ }^{20}$ Setelah itu ia melanjutkan pedidikan di Oxford University hingga mendapat gelar Bachelor of Art (1932) dan Master of Art (1937) di bidang Sastra Inggris. Setelah lulus dari Oxford, Lings mengajar Bahasa Inggris di Polandia sebentar, lalu pindah ke Vytautas Magnus University, Kaunas, Lithuania hingga tahun 1939. ${ }^{21}$

Sejak masih berkuliah di Oxford, Lings menyukai tulisan-tulisan René Guénon, seorang muallaf dan pemikir metafisika asal Prancis, dan Frithjof Schuon, seorang pakar spiritualitas asal Jerman yang saat itu sedang tinggal di Swiss. Pada Januari 1938, Lings berangkat ke Swiss untuk menemui Schuon. Sejak saat itu Lings menjadi murid sekaligus sahabat Schuon dan sering mengunjunginya sambil tetap mengajar di Lithuania.

Frithjof Schuon sendiri merupakan seorang pakar perbandingan agama yang sedari muda tertarik pada Advaita Vedânta. Karena sulit baginya untuk mempelajari Hindu di Eropa dan ajaran Kasta menghalanginya untuk menjadi guru Hindu, maka Schuon mempelajari agama lain untuk memuaskan dahaga spiritualnya. ${ }^{22}$ Schuon kemudian masuk Islam dan merasa tertarik pada tasawuf. Tahun 1932 pencariannya akan guru spiritual yang mumpuni membawanya ke Aljazair. Di tahun selanjutnya ia dibaiat ke dalam Tarekat

\footnotetext{
${ }^{18}$ Sulasman, Metodologi Penelitian Sejarah, Bandung: Pustaka Setia, 2014, hlm. 15.

${ }^{19}$ Michael Fitzgerald, "In Memoriam: Dr. Martin Lings", Vincit Omnia Veritas, Vol. II, No. 1, hlm. 89.

${ }^{20}$ Michael Fitzgerald, "In Memoriam: Dr. Martin Lings”, hlm. 90.

${ }^{21}$ Hasan Le Gai Eaton, "Martin Lings: Islamic Scholar concerned with Spiritual Crisis", https://theguardian.com/news/2005/may/27/guardianobituaries diakses pada 27 Desember 2018.

${ }^{22}$ Frithjof Schuon, The Essential Frithjof Schuon, Indiana: World Wisdom, 2005, hlm. 3-26.
} 
Alawiyah, cabang dari Tarekat Darqawiyyah, oleh Syekh Ahmad al-Alawi (w. 1934).

Lewat bimbingan Schuon-lah Lings mengucapkan dua kalimat syahadat pada tahun $1938 .{ }^{23}$ Lings segera memiliki nama baru: Abu Bakar Sirajuddin. Di tahun-tahun selanjutnya, Lings menjadi murid sekaligus sahabat Schuon. Lings juga bergabung dalam Tarekat Alawiyah-Darqawiyah sebagaimana Schuon, saat itu usianya 29 tahun.

Di tahun 1940, Lings mengunjungi seorang temannya yang merupakan sekretaris pribadi René Guénon di Mesir. Tidak lama setelah Lings tiba, temannya itu meninggal akibat sebuah kecelakaan lalu lintas. Di negeri yang masyhur dengan Sungai Nil ini Lings memperoleh pendapatan dari mengajar bahasa Inggris di University of Cairo, sambil terus menyempurnakan kemampuan bahasa Arabnya dan mempelajari Islam bersama Guénon.

Selama lebih dari satu dekade, Kairo menjadi rumah bagi Lings. Dia mengajar bahasa Inggris di University of Cairo dan bersama murid-muridnya memproduksi pertunjukan drama setiap tahun. Naskah drama buatan Shakespeare (w. 1616) merupakan favorit Lings. Baginya, syair-syair Shakespeare mengandung makna universal yang mendalam. ${ }^{24}$ Di tahun 1944 Lings menikahi Lesley Smalley dan mereka tinggal bersama di sebuah perkampungan dekat Piramida. Ketika tinggal di sana, Lings beberapa kali dikunjungi oleh Le Gai Eaton, seorang warga negara Inggris yang besar di Jamaika. Dengan bantuan Lings, Gai Eaton mengucapkan syahadat dan mendapat nama "Hasan." ${ }^{25}$ Walaupun Lings dan istrinya sudah merasa nyaman tinggal di Mesir, takdir berkata lain. Mereka terpaksa meninggalkan Mesir setelah ada huru-hara anti-Inggris yang disokong kaum nasionalis pimpinan Gamal Abdul Nasser pada tahun 1952.

Kembali ke London tanpa punya pekerjaan, Lings memutuskan untuk melanjutkan studi. Sementara Lesley memilih bekerja sebagai psikoterapis. Setelah berhasil memperoleh gelar B.A. pada program studi Bahasa Arab, dia memperoleh gelar Ph.D. dari School of Oriental and African Studies (SOAS) untuk tesisnya tentang seorang sufi terkenal asal Aljazair; Ahmad al-Alawi, yang tidak lain adalah guru dari Frithjof Schuon.

Tahun 1955, Lings bekerja sebagai asisten penjaga naskah-naskah Timur di British Museum. Pekerjaan yang menyenangkan itu dilakoninya hingga dua dekade. Tahun 1973, Lings merangkap kerja di British Library, dimana ia memfokuskan perhatiannya pada kaligrafi alquran. Sejak tahun 1970 , saat ia diangkat menjadi Kurator Bagian Naskah-Naskah dan Buku

\footnotetext{
${ }^{23}$ Martin Lings, A Return to Spirit, Kentucky: Fons Vitae, 2005, hlm. 4-5.

${ }^{24}$ Martin Lings, Shakespeare in the Light of Sacred Art, London: George Allen \& Unwin, 1966, hlm. 13 dan 124.

${ }^{25}$ Hasan Le Gai Eaton, "First Encounter”, Q-News, No. 363, Juni 2005.
} 
Ketimuran di museum tersebut, termasuk manuskrip-manuskrip al-Quran (pada tahun 1973 bagian tersebut menjadi satu dengan The British Library).

Beberapa tahun setelah masuk Islam, Lings menjadi seorang pendakwah. Ia berceramah di berbagai tempat, di Inggris maupun di bagian Eropa lainnya, dan menjadi rajin menulis. Tulisan-tulisan Lings antara lain membicarakan sufisme, sastra, sejarah, dan kekuatan seni. Setelah pensiun dari jabatan Kurator di The British Museum, Lings hidup damai bersama istrinya di Inggris. Bersamaan dengan itu pula, Lings memproduksi kembali karya-karya seminalnya, seperti What is Sufism? (1975), The Quranic Art of Calligraphy and Illumination (1976), dan Muhammad: His Life Based on the Earliest Sources (1983). Karya Lings yang disebutkan terakhir mendapat sambutan baik di berbagai tempat. Kementerian Urusan Agama Pakistan memilih karya ini sebagai pemenang pertama dalam kompetisi penulisan Sirah Rasulillah di hadapan juri ahli-ahli sirah. ${ }^{26}$

Karangan Lings banyak menyentuh wacana Islam dan Esoterisme. Dari setiap tulisannya dapat ditemukan sebuah kombinasi yang khas: antara seorang penyair dari Barat dengan seorang muslim dari Timur. Lings selalu membungkus pengetahuan agamanya dengan Bahasa Inggris, bukan bahasa Inggris biasa, tetapi yang dipakai seorang lulusan sastra Inggris dari Oxford. Bahasanya indah dan enak tanpa melupakan kaidah-kaidah dasar sebuah karya ilmiah. Perpaduan demikian terasa pula dalam Sirah Nabawiyah yang ditulis oleh Lings, ia memberinya judul; Muhammad: His Life Based on Earliest Sources. Hampir semua orang yang membacanya terpesona dengan kalimatkalimatnya yang lugas dan berseni.

Komitmen Lings terhadap Islam terbawa sepanjang hayat. Sepuluh hari sebelum meninggal dunia, Lings masih sempat menghadiri acara maulid nabi di Wembley bersama tiga ribu orang. Enam hari kemudian dia menyelesaikan suntingan buku The Underlying Religion. Di hari-hari terakhirnya Lings sempat pula menanam sebatang pohon di dekat rumahnya. ${ }^{27}$ Lings memang dikenal sebagai pecinta tumbuhan, terutama yang memiliki bunga-bunga yang elok dipandang. ${ }^{28}$ Lings wafat pada 12 Mei 2005 pada usia 96 tahun.

\footnotetext{
${ }^{26}$ Kiki Muhamad Hakiki dan Diparakhman Al Idrus, Diskursus Tasawuf di Barat: Membaca Pemikiran Martin Lings, Al-Adyan, Volume 13, No. 2, 2018.

${ }^{27}$ Reza Shah-Kazemi, “A Truly Holy Soul: a Tribute to Martin Lings, Shaykh Abu Bakr Siraj ad-Din 1909-2005”, Q-News, No. 363, Juni 2005, hlm. 52.

${ }^{28}$ Emma Anima Clark, "That is the Man who Speaks to Flowers and who is Much Loved", $Q$-News, No. 363, Juni 2005
} 


\section{Isi Buku Muhammad His Life Based on the Earliest Sources}

Secara garis besar, buku Muhammad His Life Based on the Earliest Sources oleh penulisnya penulisnya dibagi ke dalam 85 bagian yang saling berhubungan. ${ }^{29}$ Satu demi satu bagian diurutkan sesuai dengan urutan kejadian-kejadian yang mengelilingi kehidupan Nabi Muhammad. Hampir semuanya bernada kronologis, yakni berdasarkan urut waktu berlangsungnya suatu kejadian, atau dapat dibahasakan menjadi periodisasi temporal. Muhammad His Life Based on the Earliest Sources diawali dengan kisah janji Allah kepada Nabi Ibrahim bahwa ia akan segera mempunyai anak dan diakhiri dengan prosesi pemakaman Nabi Muhammad.

Penulis membagi 85 bagian dalam buku Muhammad His Life Based on the Earliest Sources ke dalam 4 kelompok; Sebelum kelahiran Nabi Muhammad, kehidupan Nabi Muhammad di Mekah, kehidupan Nabi Muhammad di Madinah, dan tema keislaman. 3 kelompok pertama menunjukkan kecenderungan periodisasi temporal, dari satu masa ke masa berikutnya. Sedang kelompok terakhir lebih cenderung tematis. Berikut rinciannya;

Buku Muhammad His Life Based on the Earliest Sources dibagi ke dalam 85 bagian, yang secara garis besar dapat dikumpulkan menjadi 4 kelompok: kelompok sebelum kelahiran Nabi Muhammad (bagian 1-6), kehidupan Nabi Muhammad di Mekah (bagian 7-37, kecuali bagian 16, 23, 25, dan 30), kehidupan Nabi Muhammad di Madinah (bagian 38-85, kecuali bagian 81, dan 82), dan tema keislaman (bagian 16, 23, 25, 30, 81, dan 82). 3 kelompok pertama menunjukkan kecenderungan periodisasi temporal, sedang kelompok terakhir lebih cenderung tematis. Kelompok sebelum kelahiran Nabi Muhammad terlebih dahulu menguraikan kisah Nabi Ibrahim dan keluarganya. Kemudian dilanjutkan dengan riwayat Qushay yang mendirikan Suku Quraisy, Abdul Manaf, Hasyim, dan seterusnya keturunan Qushay hingga Abdullah bin Abdul Muthallib; ayah dari Nabi Muhammad. Kelompok kehidupan Nabi Muhammad di Mekah mengisahkan kehidupan Nabi ketika masih di Mekah: dari kelahiran, kenabian, hingga berangkat berhijrah ke Yatsrib. Yatsrib kemudian berubah nama menjadi Madinah dan di kota ini Nabi menghabiskan sekitar 11 tahun hidupnya. Tahun-tahun itulah yang menjadi isi kelompok kehidupan Nabi Muhammad di Madinah, yang juga memuat peperangan dan kehidupan keluarganya. Sedangkan kelompok tema keislaman, yang terdiri atas enam bagian, semuanya menguraikan garis-garis besar ajaran Islam, seperti tauhid, ibadah, hari kiamat, dan maqamat.

\footnotetext{
${ }^{29}$ Lihat Martin Lings, Muhammad: His Life ..., hlm. vii-viii.
} 


\section{Analisis Historiografis Buku Muhammad His Life Based on the Earliest Sources}

Persoalan pertama metode sejarah ialah persoalan sumber. Sumber sejarah, yang berwujud benda, atau tulisan, ataupun bukan keduanya, secara umum dapat dikatakan melimpah ruah. Walaupun dapat ditemui beberapa tempat dan waktu yang sukar ditemui sumber sejarahnya yang sezaman, seperti tanah Arab di abad ke-6 dan 7 M, dimana Rasulullah hidup. Untungnya, 1,5 abad setelah kewafatan Rasulullah kitab Sirah mulai bermunculan dan setengah abad kemudian mulai banyak ditemui karya-karya seputar hadits, yang banyak mengabadikan ucapan dan perbuatan-perbuatan Nabi Muhammad. ${ }^{30}$ Tetapi apakah kitab-kitab Sirah dan hadits itu dapat diandalkan sepenuhnya?

Lings menyadari permasalahan sumber di atas. Maka sedari awal dia berhati-hati dalam memilih dan menyeleksi sumber untuk merangkai kisah hidup Nabi Muhammad. Bisa dikatakan, Lings hanya menggunakan sumber primer saja. Maka bukunya ini pun dia beri sub-judul; his life based on the earliest sources (hidup Nabi berdasarkan sumber-sumber paling awal), untuk lebih memberi gema bahwa bukunya telah menggunakan sumber yang benarbenar bisa dipercaya.

Dapat saja orang menduga bahwa Lings yang kelahiran Inggris sebenarnya sedang menuliskan sejarah Nabi sesuai dengan tradisi ilmiah Barat. Kita ketahui bahwa Eropa Barat adalah tempat lahir dan berkembangnya Historiografi Saintifik, dengan tokohnya Leopold Ranke, dimana penulisan harus berdasarkan fakta yang kuat, otentik, dan berorientasi pada dokumen (document-oriented). ${ }^{31}$ Tetapi premis ini amat lemah. Nyatanya, Lings tidak berpegang pada dogma Rankean bahwa satu-satunya sumber yang dapat dipercaya ialah dokumen atau artefak yang tercipta di waktu yang sama dengan peristiwa bersangkutan, atau harus dicipta oleh saksi mata itu peristiwa. ${ }^{32}$ Lings telah keluar dari pakem itu. Lagi pula ia sama sekali tidak mencantumkan barang satu judul buku atau sumber sekunder buatan orang Eropa Modern di bibliografi buku Muhammad-nya. ${ }^{33}$

\footnotetext{
${ }^{30}$ Sirah secara umum berarti biografi Nabi Muhammad Saw. Lihat Tarif Khalidi, Images of Muhammad: Narratives of the Prophet in Islam Across the Centuries. New York: Double Day; Tarif Khalidi, 1994. Arabic Historical Thought in the Classical Period. Cambridge: Cambridge University Press; dan Franz Rosenthal, A History of Muslim Historiography, Leiden: Brill, 1968.

31 Michel de Certeau, Heterologies: Discourse on the Other, trans. Brian Massumi, Minneapolis: University of Minnesota Press, 2000, hlm. 200.

${ }^{32}$ Thomas Gil, 'Leopold Ranke', dalam Aviezer Tucker (ed.)(2009), A Companion to the Philosophy of History and Historiography, UK: Wiley-Blackwell, hlm. 383.

${ }^{33}$ Martin Lings, Muhammad: His Life ..., hlm. 349.
} 
Di samping kitab-kitab hadis, Lings juga menambahkan sumber lain berupa kitab Sirah awal. Di antaranya ialah Sirah Nabawiyyah karya Ibnu Ishaq dan Ibnu Hisyam. Ini merupakan pilihan yang tepat karena keduanya termasuk karya biografi Nabi Muhammad yang paling awal. Khalidi menggolongkan Ibnu Ishaq dan Ibnu Hisyam sebagai founding fathers sirah. Selain kedua tokoh itu, yang termasuk founding fathers adalah al-Waqidi, Ibn Sa'ad (w. 845), al-Baladzuri (w. 892), dan ath-Thabari (w. 923). Khalidi beranggapan bahwa keenam penulis ini adalah pencetak struktur sirah sepanjang sejarah. ${ }^{34}$ Kesemuanya dirujuk Lings sebagai sumber bagi bukunya, kecuali Al-Baladzuri. ${ }^{35}$ Dengan demikian Lings telah betul-betul berusaha agar Muhammad: His Life Based on the Earliest Sources miliknya hanya menggunakan earliest sources (sumber-sumber paling awal).

Lings beberapa kali mengutip karya Imam ath-Thabari, baik Tarikh arRusul wa al-Muluk maupun Al-Bayan fi Tafsir al-Qur'an. Tetapi Lings lebih jarang menggunakan kitab Tarikh Imam Thabari dibandingkan Thabaqat alKabir Ibnu Sa'ad sebagai referensi. ${ }^{36}$ Tarikh ar-Rusul wa al-Muluk Imam Thabari dikutip sebanyak tiga kali sedangkan Thabaqat Ibnu Sa'ad sebanyak 52 kali. $^{37}$ Sirah Nabawiyah Ibnu Ishak juga dikutip, bahkan lebih sering daripada Thabaqat. Tiga kitab yang paling sering dirujuk adalah Sirah Nabawiyah Ibnu Ishak, Thabaqat al-Kabir Ibnu Sa'ad, dan diikuti Al-Maghazi Waqidi. Kitab-kitab hadis yang tergabung dalam Kutub as-Sittah (Enam Kitab Sahih) juga banyak dikutip. Kutub as-Sittah adalah enam kitab hadis yang dianggap paling dapat dipercaya kesahihannya dalam tradisi Islam Sunni. ${ }^{38}$ Penulis yang termasuk penulis Kutub as-Sittah yakni: Bukhari, Muslim, Tirmidzi, Nasa'i, Abu Dawud, dan Ibnu Majah. Lings adalah seorang muslim sunni, maka ia menulis biografi Nabi Muhammad sebagai seorang muslim sunni.

\section{Keunikan Buku Muhammad His Life Based on the Earliest Sources}

Hal unik pertama ada pada diri penulis, yakni Martin Lings. Lahir di tengah keluarga Kristen Protestan di Inggris, Lings masuk Islam di tahun 1938. Dengan memposisikan dirinya sebagai seorang muslim, maka biografi Nabi yang dia tulis ialah berbeda dengan tulisan orang Barat lainnya yang nonmuslim. Lings tidak akan menulis Nabi Muhammad sebagai seorang yang

\footnotetext{
${ }^{34}$ Tarif Khalidi, Images of Muhammad ..., hlm. 59.

35 Tanpa alasan yang jelas.

${ }^{36}$ Muhammad bin Sa'ad az-Zuhri, Kitab Thabaqat al-Kabir, Kairo: Maktabah al-Khanji, 1994.

${ }^{37}$ Martin Lings, Muhammad: His Life ..., catatan kaki.

${ }^{38}$ Fazlur Rahman, Islam: Sejarah Pemikiran dan Peradaban, Bandung: Mizan, 2016, hlm. 84-85.
} 
haus darah, seperti yang dilakukan oleh Robert Spencer. Dalam The Truth about Muhammad ia menyebut: “... Jews of Medina were next to receive the wrath of Muhammad. [orang Yahudi Madinah akan menerima kemurkaan Muhammad.]" untuk menyebut nasib suku Bani Qainuqa', Nadir, dan Quraizah yang diusir atau dibunuh hingga habis. ${ }^{39}$ Ia juga mengatakan bahwa Nabi Muhammad punya ambisi untuk meluaskan wilayahnya dan terus menambah istri-istrinya. ${ }^{40}$

Lings jelas berbeda dengan Spencer, dan berbeda pula dengan Chase Robinson atau Karen Amstrong. Chase Robinson meragukan keabsahan datadata mengenai kelahiran dan masa muda Nabi Muhammad Saw. ${ }^{41}$ Baginya masa-masa sebelum Kenabian kurang penting dan penuh dengan legenda. Sedangkan Karen Amstrong, kendati bersimpati kepada Islam dan nabinya, ia tetaplah seorang Nasrani. ${ }^{42}$ Lings berbeda, karena selain berstatus sebagai seorang cendikiawan jebolan Oxford dan London, ia juga merupakan seorang muslim yang mempraktikkan Islam setiap harinya dan mencintai Nabi Muhammad dengan sebetul-betulnya cinta.

Sedangkan dari segi isi, ada banyak sekali keunikan yang dapat ditemukan dalam buku Muhammad: His Life Based on the Earliest Sources. Untuk menjelaskan lebih lanjut bagaimana tepatnya keunikan ini, penulis akan melakukan sedikit komparasi, antara isi Muhammad: His Life Based on the Earliest Sources dengan isi buku-buku sirah lainnya. Hal ini penting mengingat keunikan hanya akan ditemukan setelah objeknya disandingkan dengan objek-objek lain. ${ }^{43}$

Karena pengaruh penulisan sejarah modern yang mengintegrasikan banyak cabang ilmu, maka sirah modern banyak yang memuat analisis sosialkultural bangsa Arab sebelum Islam terlebih dahulu. Para sejarawan muslim yakin bahwa pemahaman terhadap kehidupan di lingkungan dan zaman kelahiran Nabi, semacam bab latar belakang sebelum masuk ke pembahasan yang menjadi inti, ialah sangat diperlukan, agar kaum muslim sadar betapa kehadiran seorang Nabi sangat diperlukan ketika itu. Termasuk penulis yang bergaya seperti itu ialah Shafiyyurrahman Al-Mubarakfuri. Ia mengawali Shahih Sirah Nabawiyah-nya dengan menjelaskan suasana geopolitik di Jazirah Arab seputar abad ke-6 M. Ia jelaskan kekuatan-kekuatan politik di

\footnotetext{
${ }^{39}$ Robert Spencer, The Truth about Muhammad: Founder of the world's most intolerant religion, Washington: Regnery Publishing, 2006, hlm. 121 dan 129-133.

${ }^{40}$ Robert Spencer, The Truth about Muhammad, hlm. 123-128, 133, dan 164.

${ }^{41}$ Chase F. Robinson, 'The Rise of Islam, 600 705', dalam Chase F. Robinson dkk, The New Cambridge History of Islam, jilid 1, hlm. 183.

${ }^{42}$ Karen Amstrong, The Spiritual Staircase: My Climb Out of Darkness, New York: Anchor Books, 2004.

${ }^{43}$ Peter Burke, History and Social Theory, hlm. 29-31. Lihat juga Friedrich Nietzsche, The Gay Science: with a Prelude in German Rhymes and an Appendix of Songs, trans. Josefine Nauckhoff, Cambridge: Cambridge University Press, 2008, hlm. 145.
} 
Yaman, Hirah, Suriah, dan Hijaz. ${ }^{44}$ Begitu pula dengan agama, ekonomi, dan kultur bangsa Arab yang jelas harus diketahui pembaca. Buku-buku karya penulis Barat, seperti The Venture of Islam, sebenarnya juga biasa menyertakan deskripsi tentang kondisi Arab Pra-Islam. Tetapi antara penulis muslim dengan mereka ada perbedaan dalam hal tujuan.

Sejarawan dan Arabis seperti Marshall Hodgson berusaha menjelaskan masa pra-Islam dengan empiris. Yang ia perlukan ialah sebuah data hampir kuantitatif tentang struktur masyarakat dalam hal politik dan ekonomi. Hodgson mencari-cari kapan orang Arab mulai beternak domba, kapan mereka mulai mendirikan kota-kota, dan bagaimana interaksi antar-individu dan antar-suku. ${ }^{45}$ Sedang pertanyaan utama di kepala Al-Mubarakfuri adalah bagaimana peringai bangsa Arab dahulu. Ia betul-betul ingin menunjukkan bahwa bangsa Arab dulunya punya moralitas yang terlampau bejat: mereka rajin berjudi, mabuk, bergonta-ganti pasangan, dan suka saling membunuh. ${ }^{46}$ Penjelasannya menjadi begitu karena dikungkung oleh paham bahwa Arab sebelum Islam ialah Jahiliyyah, penuh kebodohan. ${ }^{47}$ Paham ini sudah sangat beredar luas di kalangan intelektual muslim. Sehingga dapat disimpulkan bahwa ada perbedaan mencolok antara penulis muslim dengan yang nonmuslim dalam menyikapi kehidupan bangsa Arab pra-Islam, yakni yang pertama mencari tahu kebobrokan moral dan yang kemudian mencari struktur sosial saja.

Lings dengan luar biasa dapat keluar dari kedua pakem tadi. Dalam membicarakan kondisi Timur Tengah pra-Islam, jika rata-rata penulis muslim lebih menunjukkan kebobrokan moral di masyarakat, maka Lings lebih memfokuskan diri kepada para hanif, yakni sebahagian kecil dari orang Arab yang melestarikan ajaran Nabi Ibrahim dengan menyembah Tuhan Yang Esa. ${ }^{48}$ Lings tidak ingin membatasi dirinya pada hal-hal yang presisi seperti tanggal yang pasti ataupun analisis formal-analitik khas Barat. Yang Lings lakukan ialah mengikuti penulisan sirah terdahulu dengan gayanya sendiri. Berkat adanya para hanif, masih ada orang yang beribadah kepada Allah Swt. ${ }^{49}$ Sedankan Michael Cook, dia berjanji bahwa dirinya ingin menulis biografi Nabi sesuai sumber Ibnu Ishak saja tanpa ada analisis yang serius. ${ }^{50}$

\footnotetext{
${ }^{44}$ Shafiyyurrahman Al-Mubarakfuri, Shahih Sirah Nabawiyah, hlm. 1-29.

${ }^{45}$ Marshall G. Hodgson, The Venture of Islam, jilid 1, hlm. 130-140.

${ }^{46}$ Shafiyyurrahman Al-Mubarakfuri, Shahih Sirah Nabawiyah, hlm. 44-50.

${ }^{47}$ Ludwig W. Adamec dkk., Historical Dictionary of Islam, Maryland: Scarecrow press, 2009, hlm. 146.

${ }^{4}$ Martin Lings, Muhammad: Kisah Hidup Nabi berdasarkan Sumber Klasik, Jakarta: Serambi, 2016, hlm. 21 dan 509.

${ }^{49}$ Martin Lings, Muhammad: His Life Based on the Earliest Sources, Cambridge: Islamic Texts Society, 1983, hlm. 16.

${ }^{50}$ Michael Cook, Muhammad, Oxford: Oxford University Press, 1995, hlm. 12.
} 
Tetapi eksplanasi Cook masih terasa sangat kering, tidak seperti gaya bahasa Lings yang lincah dan mudah dikonsumsi.

Hal yang semacam ini tidak dapat ditemukan dalam buku-buku biografi Nabi tulisan orang Barat lainnya. Kalaupun ada, biasanya dengan interpretasi yang terlalu liar. Maxime Rodinson, misalkan, berpendapat bahwa secara politis dikendalikan oleh tiga orang: Abu Bakar, Umar bin Khattab, dan Sa'ad bin Ubadah. Mereka bertiga inilah yang sejatinya memimpin "negara" Madinah. ${ }^{51}$ Katanya, Abu Bakar dan Umar bin Khattab dapat sedemikian dalam pengaruhnya pada pikiran Nabi karena mereka menikahkan putrinya dengan Nabi. Putri yang sekaligus menjadi istri Nabi itulah yang mengendalikan alam pikirnya setiap hari. Bagi Maxime, menikah ialah tentang mendapat pengaruh, sesuatu yang dapat disimpulkan setelah ia melihat banyak masyarakat feodal. ${ }^{52}$ Ditambah lagi Maxime lebih mempercayai konsepsi Marxisme dibandingkan dengan hadis Nabi.

Lebih jauh ia mensinyalir ada satu pemain lagi yang ingin memasuki lapangan politik Madinah, yakni Ali bin Thalib. Saat itu beliau masih muda, hampir dua puluh tahun saat Hijrah, dan sangat bersemangat. Ali adalah orang yang sangat setia pada ideal Islam dan beliau berhasil menikahi putri Nabi dari istrinya yang pertama. Karier politiknya tidak mulus, sayangnya, karena harus menghadapi perwakilan Abu Bakar, yakni Aisyah. Kita sudah melihat bagaimana Aisyah kadang bersenggolan dengan istri Ali, Fatimah, dan dengan percaya diri mengungkapkan kecemburuannya di hadapan Nabi. Perseteruan antara Fatimah (serta Ali) dan Aisyah terus terjaga panasnya bahkan sepeninggal Nabi dan kemudian Abu Bakar. Puncaknya ialah Perang Jamal, dimana Aisyah mengangkat pedang kepada Ali. ${ }^{53}$ Bagi Maxime, pernikahan, khususnya pernikahan di lingkaran Nabi Muhammad, ialah sebatas tariktambang kepentingan politik.

Harus kita akui bahwa dalam berkeluarga, Nabi ialah seorang manusia sebagaimana kita, yang senang dengan kehadiran istri yang setia dan anak yang berbakti. Betul bahwa beberapa pernikahan Nabi bertujuan untuk menguatkan hubungan dan persaudaraan dengan berbagai kabilah. ${ }^{54}$ Bahkan, menurut Husain Haekal, Nabi mengawini Hafsah semata-mata karena Umar, sedikit pun bukan karena cinta birahi. ${ }^{55}$ Sistem kekerabatan dapat pula menjelaskan mengapa terjadi Perang Ahzab. Sebagian besar muslim yang

\footnotetext{
${ }^{51}$ Maxime Rodinson, Mohammed, hlm. 222.

${ }^{52}$ Maxime Rodinson, Islam and Capitalism, trans. Brian Pearce, New York: Penguin Books, 1973, hlm. 28-68.

${ }^{53}$ Maxime Rodinson, Mohammed, hlm. 222-223.

${ }^{54}$ Muhammad Fethullah Gulen, The Essentials of Islamic Faith, New York: Feedbooks, 2005, hlm. 181-185.

${ }^{55}$ Muhammad Husain Haekal, Sejarah Hidup Muhammad, terj. Ali Audah, Jakarta: Pustaka Jaya, 419-420.
} 
berhijrah ke Madinah adalah sanak keluarga bagi orang Mekah. Kendati keimanan telah memisahkan mereka, tetaplah menjadi aib bagi orang Mekah jika mereka membunuh kerabat mereka sendiri. Maka mereka memilih untuk menjalin persekutuan dengan suku-suku ( $a h z a b)$ Badui di padang pasir. Jika kerabat mereka yang muslim itu terbunuh oleh tangan orang Badui, maka hal itu lebih mereka sukai ketimbang oleh tangan mereka sendiri. ${ }^{56}$

Penjelasan perihal laku yang sekompleks demikian tidak akan dapat ditemukan dalam karangan-karangan orientalis karena mereka adalah orang Eropa modern yang sudah individualistik. Georg Simmel telah menjelaskan bagaimana di abad ke-19 individualisme semakin menjadi-jadi di Eropa. Individualisme yang awalnya berdasarkan pada Einzigkeit (keunikan) kini berdasar pada Einzelheit (kesendirian) yang ekstrim. ${ }^{57}$ Sehingga yang kita dapati adalah sebuah masyarakat yang terpisah dari "masyarakat" dan, lebih lagi ketika pernikahan sebatas menjadi opsional jika seseorang ingin memiliki keturunan, tidak akan dapat memahami apa itu kekerabatan. Humanism begitu nama lain individualisme di Eropa - bagi Lings ialah sebuah fantasi yang akan menghancurkan Barat, alih-alih memajukannya. ${ }^{58}$

Keunikan lain dari buku Muhammad: His Life Based on the Earliest Sources ialah saat Lings menulis: “... generally speaking, whereas the Arabs were in favour of the man but against the message, the Jews were in favour of the message but against the man. [Secara umum, jika orang Arab menyukai orangnya [Nabi Muhammad] tetapi menolak ajarannya, maka orang Yahudi menyukai ajarannya tetapi menolak orangnya]. ${ }^{59}$ Dengan ini Lings bukan hanya menceritakan kisah hidup Nabi secara deskriptif-naratif, tetapi juga menambahkan nuansa analitik dalam bukunya. Rata-rata memang Lings memberi generalisasi pada perilaku kolektif orang Yahudi, seperti di bagian 39 dan $61 .^{60}$ Hubungan Nabi dengan kaum Yahudi memang ambivalen: kadang bersahabat dan kadang bermusuh-musuhan. Saat beliau datang ke Madinah pemuka-pemuka Yahudi juga ikut menyepakati Piagam Madinah dimana masing-masing pihak sepakat untuk hidup damai di Madinah dan akan saling bahu-membahu jika ada serangan dari luar. Tetapi kemudian orangorang Yahudi sendiri yang berkhianat. Maka Nabi Muhammad pun mengusir dua suku Yahudi, yakni Bani Qainuqa' dan Nadir. ${ }^{61}$

Bagi penulis Barat semacam Spencer dan Maxime, pengusiran tersebut ialah semata-mata akibat dari rasa dendam di dada Nabi. Juga bahwa Nabi

\footnotetext{
${ }^{56}$ Martin Lings, Muhammad: His Life ..., hlm. 215-222.

${ }^{57}$ Georg Simmel, The Sociology of Georg Simmel, trans. Kurt H. Wolff, New York: The Free Press, 1950, hlm. 81.

${ }^{58}$ Martin Lings, Ancient Beliefs and Modern Superstitions, London: Quinta Essentia, 2001.

${ }^{59}$ Martin Lings, Muhammad: His Life ..., hlm. 57.

${ }^{60}$ Martin Lings, Muhammad: His Life ..., hlm. 125 dan 229.

${ }^{61}$ Martin Lings, Muhammad: His Life ..., hlm. 160 dan 203.
} 
memang berencana untuk menyingkirkan semua saingan politiknya, dengan jalan diusir ataupun dipenggal. ${ }^{62}$ Tidak dapat dipungkiri bahwa Yahudi memang bersaing untuk mendapat supremasi politik dengan Nabi. Mereka dulunya mendominasi pasar dengan memainkan monopoli. ${ }^{63}$ Serangkaian perang Nabi dengan Quraisy dan infiltrasi muslim-muslim Mekah, yang ratarata ialah pengusaha-pengusaha ulet, di pasar Madinah jelas menipiskan supremasi mereka. Akhirnya ada di antara mereka yang membantu militer Mekah untuk menamatkan kepemimpinan Nabi. Nabi yang mengetahui hal ini harus bertindak tegas, agar kedamaian di Madinah tetap terjaga. Apalagi pedagang Yahudi dari Bani Qainuqa' pernah dengan lancang melecehkan seorang muslimah di pasar. ${ }^{64}$ Bahkan Nabi sendiri pernah coba dibunuh oknum Yahudi Bani Nadir. ${ }^{65}$ Maka pengusiran menjadi hukuman yang setimpal, mengingat orang zaman itu hidup secara kolektif atau, meminjam istilah Max Weber, sebuah patrimonial society. ${ }^{66}$

Tilman Nagel dengan berat hati memuat kisah ini dalam bukunya yang berjudul Mohammed: Leben und Legende. Nagel menulis bahwa peristiwa Nabi Muhammad yang dinaungi awan ketika pergi ke Suriah sebagai legende (legenda). Ia juga mencurigai Nabi sebagai orang yang memang ingin punya pengaruh di kalangan Quraisy, sesuatu yang akan dirinya capai dengan mengarang lebih banyak legenda lagi. Sikap berbeda diambil Martin Lings, yang mempercayai adanya awan ang selalu menaungi Nabi dan melihat bahwa Nabi memang ditakdirkan untuk memimpin semua orang Arab dan yang bukan Arab.

Secara singkat, keunikan yang terdapat dalam buku Muhammad His Life based on the Earliest Sources karya Martin Lings ialah; Menggunakan sumber-sumber yang otentik dan terpercaya, Menawarkan interpretasiinterpretasi baru, ditulis dengan bahasa yang indah dan tinggi, serta memadukan analisis sosial-kultural dengan apa yang dikatakan kitab-kitab suci dan hadis Nabi. Dapat dikatakan, Muhammad His Life Based on the Earliest Sources karya Martin Lings ialah buku Sirah Nabawiyah terbaik dari abad ke-20.

\section{Simpulan}

62 Maxime Rodinson, Mohammed, hlm. 172-174. Robert Spencer, The Truth about Muhammad, hlm. 100-101.

${ }^{63}$ Shafiyyurrahman al-Mubarakfury, Shahih Sirah Nabawiyyah, hlm. 225-230.

${ }^{64}$ Martin Lings, Muhammad: His Life ..., hlm. 161.

${ }^{65}$ Martin Lings, Muhammad: His Life ..., hlm. 203-204.

${ }^{66}$ Patrimonial society punya ciri-ciri: wilayah yuridiksi yang belum begitu jelas, hierarki bersifat informal, rekruitmen dan pelatihan aparat bersifat informal, aparatnya bertugas paruhwaktu, dan koordinasi yang sebagian besar secara oral. Lihat Max Weber, The Theory of Social and Economic Organization, trans. Talcott Parsons, Illinois: Falcon's Wing Press, 1947, hlm. 329-336 dan 341-350; Peter Burke, History and Social Theory, hlm. 30-31. 
Buku Muhammad: His Life Based on Earliest Sources pertama kali terbit pada tahun 1983. Penulisnya ialah Martin Lings, yang setelah masuk Islam mendapat nama Abu Bakar Sirajuddin, sedang penerbitnya Islamic Texts Society, yang berkantor di kota Cambridge, Inggris. Martin Lings lahir di Lancashire, Inggris tahun 1909 dan wafat pada 12 Mei 2005 di London. Corak penulisan Buku Muhammad His Life based on the Earliest Sources karya Martin Lings ialah genre Sirah yang termasuk dalam tradisi biografi dalam historiografi kaum muslim. Keunikan yang terdapat dalam buku Muhammad His Life based on the Earliest Sources karya Martin Lings ialah antara lain; pertama penulisnya ialah seorang muslim sekaligus sufi. Kedua dari segi metode menggunakan sumber-sumber yang otentik dan terpercaya dan ditulis dengan bahasa yang indah dan padat. Ketiga dari segi analisis Memadukan analisis sosial-kultural dengan pemahaman skriptural dari kitab suci dan hadis, mengakui pentingnya sebab langsung dan tak langsung dengan kontekstualisasi yang tepat, serta tidak ragu dalam memuat kisah tentang mukjizat dan keajaiban-keajaiban pada diri Nabi ketika hal tersebut diakui oleh mayoritas historiografi muslim. Lings benar-benar berbeda dengan penulis-penulis Barat lain. 


\section{Daftar Pustaka}

A. Bennigsen, "Al-Bukhari, Muhammad b. Ismail” dalam H. A. R. Gibb dkk, The Encyclopaedia of Islam New Edition, jilid 1, 1997.

A. J. Wensinck, A Handbook of Early Muhammadan Tradition, Leiden: Brill, 1927.

Abdurrahman bin Ali bin al-Jawzi, Manaqib Imam Ahmad bin Hanbal, Beirut: Dar al-Hijr, 1409 H/1988 M.

Abi al-Muhasin Yusuf bin Taghribardi al-Atabaki, An-Nujum az-Zahirah fi Muluk al-Mishr wa al-Qahirah, jilid 6, Mesir: Dar al-Kitab, 1968.

Abu Bakar Ahmad bin Ali bin Tsabit al-Khatib al-Baghdadi, Tarikh Madinah as-Salam wa Akhbar Muhadditsiha wa Dzikr Quththaniha al-'Ulama, jilid 5, Beirut: Dar al-Gharb al-Islami, 2001.

Abu Nashr Abdul Wahab bin Ali as-Subki, Thabaqat asy-Syafi'iyyah alKubra, jilid 2, hlm. Beirut: Dar Ihya, 1964

Ahmad bin Ali bi Hajar al-'Asqalani, Lisan al-Mizan, jilid 7, Beirut: Dar alBasyair al-Islamiyyah, 2002.

Ajid Thohir, Sirah Nabawiyah: Nabi Muhammad Saw dalam Kajian Ilmu Sosial-Humaniora, Bandung: Penerbit Marja, 2014.

Al-Qur'an Terjemah Departemen Agama RI. 2004.

Anissia Lailatul Fitri, Sistem Pendidikan Islam Nabi Muhammad SAW pada Buku Muhammad Super Leader Super Manager Karya Syafi'i Antonio, skripsi UIN Maulana Malik Ibrahim, 2016.

Badri Yatim, Historiografi Islam, Jakarta: Logos Wacana Ilmu, 1997.

Boaz Shoshan, Poetics of Islamic Historiography: Deconstructing Tabari's History, Leiden: Brill, 2004.

Chase F. Robinson, 'The Rise of Islam, 600 705', dalam Chase F. Robinson dkk, The New Cambridge History of Islam, jilid 1, Cambridge: Cambridge University Press, 2010.

Chase F. Robinson, Islamic Historiography, Cambridge: Cambridge University Press, 1991.

Edward Said, Orientalism, New York: Vintage Books, 1979.

Emma Anima Clark, "That is the Man who Speaks to Flowers and who is Much Loved", Q-News, No. 363, Juni 2005.

Fazlur Rahman, Islam: Sejarah Pemikiran dan Peradaban, Bandung: Mizan, 2016.

Franz Rosenthal, A History of Muslim Historiography, Leiden: Brill, 1968

Fred M. Donner, Narratives of Islamic Origin: The Beginnings of Islamic Historical Writing, Princeton: Darwin Press, 1998.

Friedrich Nietzsche, The Gay Science: with a Prelude in German Rhymes and an Appendix of Songs, trans. Josefine Nauckhoff, Cambridge: Cambridge University Press, 2008, 
Frithjof Schuon, The Essential Frithjof Schuon, Indiana: World Wisdom, 2005.

G. H. A. Juynboll dkk, Encyclopaedia of Islam Second Edition, Brill: Leiden, 2012.

Georg Simmel, The Sociology of Georg Simmel, trans. Kurt H. Wolff, New York: The Free Press, 1950.

Gregor Schoeler, The Biography of Muhammad: Nature and Authenticity, New York: Routledge, 2011.

Helius Sjamsudin, Metodologi Sejarah, Yogyakarta: Ombak, 2007.

Ismail bin Umar bin Katsir ad-Dimasyqi, Al-Bidayah wa an-Nihayah, 21 jilid, Giza: Hijr, 1997.

Jacob Neusner, Judaism: the Basics, Routledge: New York, 2006

Jane Dammen McAuliffe dkk, The Cambridge Companion to the Quran, Cambridge: Cambridge University Press, 2006.

Johann W. Fück, “Al-Azraki” dalam H. A. R. Gibb dkk, The Encyclopaedia of Islam New Edition, jilid 1, Leiden: Brill, 1986.

John V. Tolan, Saracens: Islam in the Medieval European Imagination, New York: Columbia University Pres, 2002.

Jonathan A. C. Brown, Misquoting Muhammad: the Challange and Choices of Interpreting the Prophet's Legacy, London: Oneworld Publication, 2014.

K. V. Zettersteen, "Aban b. Uthman" dalam H. A. R. Gibbs dkk., Encyclopaedia of Islam New Edition, jilid 1, Leiden: Brill, 1986.

Karen Amstrong, The Spiral Staircase: My Climb Out of Darkness, New York: Anchor Books, 2004.

Karen Armstrong, Muhammad: A Prophet of Our Time, New York: HarperCollins, 2011

Ludwig W. Adamec dkk., Historical Dictionary of Islam, Maryland: Scarecrow press, 2009.

Marshall G. Hodgson, The Venture of Islam, jilid 1, Chicago: University of Chicago Press, 1964.

Martin Lings dan Clinton Minnaar (ed.), The Underlying Religion: An Introduction to the Perennial Philosophy, Indiana: World Wisdom, 2007.

Martin Lings, A Return to Spirit, Kentucky: Fons Vitae, 2005.

Martin Lings, A Sufi Saint of the Twentieth Century: Shaikh Ahmad al- 'Alawi, His Spiritual Heritage and Legacy, Cambridge: Islamic Texts Society, 1993.

Martin Lings, Ancient Beliefs and Modern Superstitions, London: Quinta Essentia, 2001.

Martin Lings, Collected Poems, London: Archetype, 2001. 
Martin Lings, Muhammad: His Life Based on the Earliest Sources, Cambridge: Islamic Texts Society, 1983.

Martin Lings, Muhammad: Kisah Hidup Nabi berdasarkan Sumber Klasik, Jakarta: Serambi, 2016.

Martin Lings, Shakespeare in the Light of Sacred Art, London: George Allen \& Unwin, 1966.

Martin Lings, What is Sufism?, Cambridge: Islamic Texts Society, 1993.

Max Weber, The Theory of Social and Economic Organization, trans. Talcott Parsons, Illinois: Falcon's Wing Press, 1947.

Maxime Rodinnson, Mohammed, trans. Anne Charter, Middlesex: Pelican Books, 1985

Maxime Rodinson, Islam and Capitalism, trans. Brian Pearce, New York: Penguin Books, 1973.

Michael Cook, Muhammad, Oxford: Oxford University Press, 1995.

Michael Cooperson, Classical Arabic Biography: The Heirs of the Prophet in the Age of al-Ma'mun, Cambridge: Cambridge University Press, 2004.

Michel de Certeau, Heterologies: Discourse on the Other, trans. Brian Massumi, Minneapolis: University of Minnesota Press, 2000.

Muhammad bin Ishak al-Madani, As-Sirah an-Nabawiyah, Beirut Dar Kitab al-'Ilmiyah, 2004

Muhammad bin Ismail al-Bukhari, At-Tarikh al-Kabir, jilid 1, Beirut: Dar alKitab al-'Ilmiyah, 2009.

Muhammad bin Sa'ad al-Baghdadi az-Zuhri, Thabaqat al-Kabir, jilid 9, Kairo: Maktabah al-Khanji, 1994.

Muhammad Fethullah Gulen, The Essentials of Islamic Faith, New York: Feedbooks, 2005.

Muhammad Husain Haekal, Sejarah Hidup Muhammad, terj. Ali Audah, Jakarta: Pustaka Jaya

Oliver Leaman, An Introduction to Classical Islamic philosophy, Cambridge: Cambridge University Press, 2004.

Paul Veyne, Writing History: Essay on Epistemology, Connecticut: Wesleyan University Press, 1984.

Peter Burke, History and Social Theory, New York: Cornell University Press, 1992.

R.G. Khoury, "Wahb b. Munabbih", dalam Peri Bearman dkk., Encyclopaedia of Islam New Edition, jilid 11, Leiden: Brill, 1997.

Robert Spencer, The Truth about Muhammad: Founder of the world's most intolerant religion, Washington: Regnery Publishing, 2006,

Sartono Kartodirdjo, Pendekatan Ilmu Sosial dalam Metodologi Sejarah, Jakarta: Gramedia, 1992.

Seyyed Hossein Nasr, Muhammad: Man of God, Chicago: ABC International Group, 1995. 
Shafiyyurrahman al-Mubarakfury, Shahih Sirah Nabawiyah, terj. Zenal Mutaqin, Bandung: Penerbit Jabal, 2014

Sulasman, Metodologi Penelitian Sejarah, Bandung: Pustaka Setia, 2014.

Syamsuddin Ahmad bin Muhammad bin Khallikan, Wafayat al-A'yan wa Anba Abna' az-Zaman, jilid 1, Beirut: Dar Shadr, 1978.

Syamsuddin Muhammad bin Ahmad bin Utsman adz-Dzahabi, Siyar A'lam an-Nubala, jilid 12, Beirut: Muassasah Risalah, 1996.

Syamsuddin Muhammad bin Ali bin ahmad ad-Dawudi, Thabaqat alMufassirin, jilid 2, Beirut: Dar 'Ilmiyyah, 1983.

Tarif Khalidi, Arabic Historical Thought in the Classical Period, Cambridge: Cambridge University Press, 1994.

Tarif Khalidi, Images of Muhammad: Narratives of the Prophet in Islam Across the Centuries. New York: Double Day, 2005.

The Holy Bible English Standard Version, Illinois: Crossway Bibles, 2007.

Thomas Gil, 'Leopold Ranke', dalam Aviezer Tucker dkk. 2009. A Companion to the Philosophy of History and Historiography. Sussex: Blackwell Publishing.

Tilman Nagel, Mohammed: Leben und Legende, München: Oldenbourg Verlag, 2008.

Tim Prodi Ilmu Sejarah, Pedoman Penulisan Tugas Akhir Ilmu Sejarah, Yogyakarta: Ilmu Sejarah Fakultas Ilmu Sosial Universitas Negeri Yogyakarta, 2013.

Zaid Ahmad, "Muslim Philosophy of History" dalam Aviezer Tucker dkk., A Companion to the Philosophy of History and Historiography, Sussex: Blackwell Publishing, 2009. 